\title{
INERANSI ALKITAB DAN IMPLIKASINYA BAGI KEHIDUPAN ORANG-ORANG PERCAYA
}

\section{Sunarto}

\section{PENDAHULUAN}

Ajaran ineransi (inerrany) Alkitab sangat penting untuk dipahami oleh semua orang percaya. Ineransi Alkitab penting untuk dipelajari karena berkaitan dengan fondasi bagi iman Kristen. Alkitab menjadi fondasi bagi iman Kristen karena menjadi rujukan bagi orang-orang percaya dalam mengambil keputusan ketika menghadapi berbagai kesulitan kehidupan. Sebaliknya apabila fondasinya tidak kuat akan menentukan cara-cara orang-orang percaya dalam mengambil setiap keputusan. Doktrin ineransi sangat penting sebab dengan menolak dokrin ini bias berakibat pada penyangkalan doktrin-doktrin Kristen lainnya. Karena itu seperti yang dikatakan oleh Rick Cornish ajaran ineransi "berfungsi sebagai jangkar iman Kristen, dan kita tidak rela membiarakannya lenyap". ${ }^{1}$

Dalam2 Timotius 4:16 dikatakan dengan jelas bahwa Alkitab menjadi dasar pedoman bagi kehidupan orang-orang percaya. Mazmur 119:105 mengatakan, "Firman-Mu itu pelita bagi kakiku dan terang bagi jalanku." Hal ini jelas memberikan pengertian bahwa pandangan seseorang terhadap Alkitab sangat terkait erat dalam memperlakukan terhadap Alkitab itu sendiri. Apa yang dipercayai itulah yang menjadi pedoman bagi setiap orang percaya. Apa yang terjadi jika yang dipercayai ternyata memiliki satu kelemahan, hal ini pasti berdampak dengan semua doktrin iman Kristen lainnnya.

Penting untuk diketahui bahwa sejak awal gereja mula-mula selalu berpegang bahwa Alkitab itu bersifat ineransi atau sempurna adanya. Begitu juga bapak-bapak gereja seperti Ireneus (abad ke 2), Cyril (abad ke-4), Agustinus (abad ke-5) dan tokoh reformasi Luther dan Calvin (abad ke-16) semua berpegang pada dokrin ineransi. Demikianjugatokoh-tokohrohaniWesminster (abadke 17), semuaberpegangpadadoktrin yang berhargaini.Dalam perkembangannya dengan adanya arus modernisme secara perlahah-lahan ada

${ }^{1}$ Rich Cornish, 5 MenitTeologi, (Bandung: Pioner Jaya, 2007) 58. 
sebagian orang Kristen yang mulai meragukan bahwa Alkitab itu ineransi mutlak. $^{2}$

Munculnya teori "kritik sumber" terutama dari pemikiran teori kritik tinggi (higher critism) yang berpresuposisi bahwa Alkitab tidak sempurna ${ }^{3}$ ikut mempengaruhi orang dalam meragukan kebenaran firman Tuhan. Maka lahirlah teori dua sumber dari Astruc (yakni, dukumen YHWH-istik dan dukumen Elohimistik) dan berikutnya muncul teori "hipotesis dukumenter" yang mengklaim bahwa Kitab Pentateukh merupakan himpunan setidaknya ada empat dukumen sumber (teori JEDP) yang menggantikan dua teori sumber. ${ }^{4}$ Orang yang menganut pada Hipotesis Dukumen mengajarkan bahwa kelima Alkitab pertama ditulis sekitar seribu tahun sesudah kematian Musa dan merupakan hasil dari proses penulisan seperti penulisan ulang, penyuntingan, dan kompilasi oleh berbagai penyunting atau redaktur yang tidak diketahui namanya. ${ }^{5}$ Pandangan tersebut jelas berlawanan dengan pandangan konservatif (ortodoks) yang menyakini bahwa Kitab Pentateukh hanya ditulis oleh seorang penulis, yaitu Musa.

Berdasarkan fakta tersebut maka sangat penting untuk mempelajari topik ineransi bagi setiap orang percaya. Pemahaman yang salah bisa menyebabkan orang Kristen akan menilai Alkitab bukan sebagai satu-satunya pedoman bagi kehidupannya. Akibat yang lain adalah orang Kristen bisa mencari kebenaran lain di luar Alkitab dan menempatkan Alkitab seperti buku-buku umum lainnya. Untuk itu penting sekali memahami dengan benar doktrin ineransi bagi setiap orang percaya, karena pemahaman yang salah dapat berimplikasi bagi kehidupan orang Kristen secara luas.

Makajelaslahbahwa pandangan seseorangterhadapineranciAlkitab dapat berimplikasi secara luas bagi kehidupan orang-orang percaya. Berdasarkan latar belakang tersebut dapat dirumuskan pokok-pokok permasalahan sebagai berikut:Apakah yang dimaksud dengan pengertian ineransi?Apakah ada dasar Alkitab bagi ajaran ineransi?Apakah implikasinya ajaran ineransi bagi kehidupan orang-orang percaya?

2 W. Gary Crampton, Verbum Dei (Surabaya: Momentum Christian Leterature, 2000) 66.

${ }^{3}$ Ibid, 69.

${ }^{4} \mathrm{Ibid}, 70$.

5 Josh McDowell, ApologetikaBukti yang MenegubkanKebenaranAlkitab (Malang: Gandum Mas, 2003) 85. 
Adapuntujuan dari penulisanmakalahadalah:Pertama, menjelaskan pengertian yang benar tentang ajaran ineransi.Kedua, memaparkan dasar Alkitab bagi pengajaran ineransi.Ketiga, memaparkan implikasi ajaran ineransi bagi kehidupan orang-orang percaya.

\section{TINJAUAN UMUM BERBAGAI PANDANGAN INERANSI}

\section{Pengertian Ineransi (Inerrancy)}

Ineransi adalah keyakinan bahwa Alkitab secara keseluruhan, yaitu Perjanjian Lama dan Perjanjian Baru adalah firman Allah yang tertulis dan tanpa salah pada naskah aslinya. Maka untuk memahami arti Alkitab seseorang harus menafsirkan dengan mempertimbangkan latar belakang kebudayaan dan standar

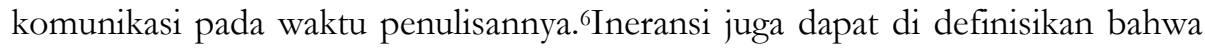
Alkitab memiliki kualitas bebas dari segala kesalahan. Firman Allah tidak dapat salah dan tidak menyatakan sesuatu yang bertentangan dengan fakta. Walaupun sebagian orang ada yang berusaha untuk mempertentangkan antara doktrin ineransi dan doktrin infalibilitas, tetapi pada dasarnya keduanya sama-sama mengajarkan dan menekankan bahwa Alkitab adalah tanpa cacat.

Harus diakui juga bahwa pengajaran ineransi tidak mengajarkan bahwa salinan atau terjemahan Alkitab itu sempurna adanya, karena pengajaran ineransi berarti sedang membicarakan tentang manuskrip yang asli. Kalau terjemahan Alkitab tidak menjamin sempurna adanya, apakah hal ini mempengaruhi akurasi Alkitab? Kritik teks setuju bahwa dalam terjemahan yang baik, tidak sampai satu dalam seribu kata yang dipertanyakan selama teks asli itu diperhatikan. Karena itu ketika seseorang membaca Alkitab dengan terjemahan yang baik, ia dapat membaca dengan kepastian bahwa terjemahan tersebut menyampaikan firman Tuhan dengan derajat akurasi yang tertinggi.7 Seperti yang dikatakan oleh Rick Cornish demikian: "Melalui upaya kritik teks (textual criticism), rekonstruksi naskah dapat dilakukan hingga mencapai tingkat akurasi tanpa kesalahan lebih dari 99 persen". ${ }^{8}$

6 Daniel Lucas Lukito, PengantarTeologia Kristen, Jilid 1 (Bandung: YayasanKalamHidup, tt.) 108.

7 W. Gary Crampton, Verbum Dei, 63-64.

${ }^{8}$ Rich Cornish, 5 MenitTeologi, (Bandung: Pioner Jaya, 2007) 57. 


\section{Full Inerrancy/Complete Inerrancy}

Pandangan "FullInerrancy" dianut oleh Harold Lindsell, Roger Nicole dan Millard Erickson. Pandangan ini mengajarkan demikian:

The Bible is fully true in all it teaches or affirms. This extends to the areas of both history and science. It does not hold that the Bible has a primary purpose to prisent exact information concerning history and science. Therefore the use of popular expressions,approximations, and phenomenal language is acknowledged and is believed to fulfill teh requirement of truthfulness. Apparent discrepancies, therefore, can and must be harmonized. ${ }^{9}$

Penulis sependapat dengan pandangan tersebut karena memang Alkitab bukan buku teks ilmiah yang bertujuan memberikan data-data ilmiah dan tentang sejarah, tetapi apabila di dalam Alkitab menyajikan pernyataanpernyataan yang berkaitan dengan sains dan sejarah, pernyataan-pernyataan tersebut benar adanya dan bukan menyesatkan. Semua yang dipaparkan atau dicatat oleh Alkitab benar adanya seperti yang dilihat oleh penulis dan saksi mata. ${ }^{10}$

\section{LimitedInerrancy}

Pandangan "LimitedInerrancy" dianut dan diajarkan oleh Daniel Fuller, Stephen Davis dan William LaSor. Pandangan ini mengajarkan demikian:

The Bible is inerrant only in its salvafic doctrinal teachings. The Bible was not intended to teach science or history, nor did God reveal matters of history or science to the writers. In these areas the Bible reflects the understanding of its culture and may therefore contain errors. ${ }^{11}$

${ }^{9}$ H. Wayne House, Charts of Christian Theology \& Doctrine (Grand Rapids: Zondervan Publisheng House, 1992) 24.

${ }^{10}$ Daniel Lucas Lukito, PengantarTeologia Kristen, Jilid 1, 122.

${ }^{11}$ H. Wayne House, Charts of Christian Theology \& Doctrine, 24. 
Penulis tidak setuju dengan pandangan Limited Inerrancy (Ineransi terbatas) yang mengajarkan bahwa sifat ineransi di dalam Alkitab hanya yang berkaitan dengan doktrin-doktrin yang berhubungan dengan keselamatan. Alkitab bersifat ineransi apabila hal itu berkaitan dengan ajaran-ajaran keselamatan. Sebaliknya pernyataan-pernyataan di dalam Alkitab yang berkaitan dengan sains, sejarah, geografi dan tidaklah bebas dari kesalahan. Kalau di dalam Alkitab ada sesuatu pernyataan yang tidak sempurna, walaupun itu hanya sebagaian saja hal ini jelas mempengaruhi otoritas Alkitab sendiri sebagai pedoman kehidupan bagi orang percaya.

\section{Inerrancy of Purpose}

Pandangan "Inerrancyof Purpose" dianut oleh Jack Rogers dan James Orr. Pandangan ini mengajarkan demikian:

The Bible is without error in accomplishing its primary purpose of bringing people into personal fellowship with Christ. The Scriptures, therefore, area truthful (inerrant) only in that they accomplish their primary purpose, not by being factual or accurate in wahat they assert. ${ }^{12}$

Pandangan ini mengatakan bahwa Alkitab tidak bersalah dalam melaksanakan maksud penulisannya. Maksud penyataan Alkitab adalah menuntun manusia kepada persekutuan pribadi dengan Kristus. Namun bukan hal yang tepat bila mengaitkan sifat tidak mungkin salah dengan hal-hal yang faktual. Jadi sifat tidak mungkin salah yang faktual merupakan istilah yang tidak cocok.

\section{The Irrevancy of Inerrancy}

Pandangan "The Irrelevany ofInerrancy" dianut dan diajarkan oleh David Hubbard. Pandangan ini mengajarkan demikian:

Inerrancy is essentially irrelevant for a varierty of reasons: (1) inerrancy is a negative concept. Our view of Scripture should be positive. (2)

${ }^{12}$ Ibid. 
Inerrancy is an unbiblical concept. (3)Error in the Scriptures is a spiritual or moral matter, not an intellectual one. (4) Inerrancy focuse our attention on minutiae, rather than on the primary concers of Scripture. (5) Inerrancy hinders honest evaluation of the Scriptures. (6) Inerrancy creates disunity in the church (this view is smilliar to the inerrancy of Pupose view.). ${ }^{13}$

Penulis tidak sependapat dengan pandangan ini, walaupun istilah ineransi sebuah istilah yang negatif, tetapi pernyataan negatif kadang sangat diperlukan untuk memberi satu penegasan. Istilah yang negatif bisa dipakai untuk memperjelas sebuah makna kata atau kalimat. Doktrin ineransi tidak secara langsung diajarkan di dalam Alkitab, tetapi doktrin ini jelas merupakan akibat logis yang diajarkan Alkitab secara tidak langsung. Alkitab adalah firman Allah dan Allah tidak dapat berbuat salah. Jadi kesimpulanya adalah Alkitab tidak dapat berbuat salah.

\section{Dasar Alkitab bagi Doktrin Ineransi}

Istilah ineransi tidak secara langsung diajarkan di dalam Alkitab, walaupun demikian doktrin ini jelas merupakan akibat logis yang diajarkan Alkitab secara tidak langsung. Berikut ini dasar-dasar yang menjadi pijakan bahwa Alkitab mempunyai sifat ineransi.

\section{Allah tidak dapat berbuat salah}

Satu argumen yang paling kokoh bahwa Alkitab bersifat ineransi adalah karakter pribadi Allah itu sendiri. Allah itu pribadi yang tidak dapat berbuat salah (Ibrani 6:18; Titus 1:2; Roma 3:4). Kalau Allah sebagai pribadi tidak dapat berbuat salah, dan Alkitab adalah perkataan-perkataan Allah, maka kesimpulannya semua yang dikatakan dalam Alkitab itu benar adanya. Sebaliknya jika Allah bisa berbuat salah, maka semua tulisan yang terdapat di dalam Alkitab tidak dapat dijamin kebenarannya.

Apa yang rencanakan Allah pasti terlaksana (Yesaya 46:11; Yeremia 51:12). Manusia, kelompok orang atau bangsa-bangsa bisa membuat rencana tetapi kalau hal itu tidak dikendaki oleh Allah pasti gagal. Semua yang direncanakan

\footnotetext{
13 Ibid.
} 
Allah tidak dapat digagalkan oleh siapapun termasuk iblis atau setan sekalipun. Berkaitan dengan penulisan Alkitab semua yang dikendaki oleh Allah untuk ditulis melalui hamba-hambaNya pasti akan terlaksana.

Pribadi Allah itu Mahabenar adanya (Mazmur 25:8). Berbeda dengan manusia sebagai pribadi yang telah jatuh dalam dosa apa yang dikerjakan belum tentu benar. Allah sebagai pribadi yang Mahabenar artinya apa yang diucapkan pasti benar, apa yang direncankan pasti terlaksana dan apa yang ditulis dalam Alkitab juga pasti benar adanya. Walaupun penulisannya adalah orang berdosa, namun inisiatornya adalah Allah yang tidak mungkin berbuat salah. Potensipotensi individual (kekurangan dan kelebihan) si penulis secara utuh berada dalam pimpinan Roh Kudus dan Allah bisa menjaga dari semua kesalahan.

\section{Alkitab ditulis dengan proses inspiransi dari Allah}

Inspirasi dapat diartikan Allah memimpin para penulis sehingga mereka dapat menuliskan pesan-Nya dalam Alkitab. Inspirasi juga dapat diartikan Allah mengawasi sedemikian rupa sehingga para penulis Alkitab itu dapat menyusun dan mencatat pesan-Nya kepada manusia dalam bentuk kata-kata pada penulisan aslinya. ${ }^{14}$ Dalam inspirasi berarti ada pengaruh adikodrati Roh Kudus atas para penulis Alkitab sehingga membuat hasil karya mereka menjadi satu catatan yang akurat tentang penyataan atau yang mengakibatkan karya mereka benar-benar merupakan firman Allah. ${ }^{15}$ Doktrinineransidaninspirasiberjalansecarabersamasama.

Sumberilahidanprosesnyamenuntuttidakadanyakesalahandalamprodukhasilnya.In spirasimengacupadasumberilahidan proses penulisanAlkitab; sedangkanineransimengacupadaprodukhasilinspirasitersebutsehinggaAlkitabbeba sdarisegala kesalahan. ${ }^{16}$

Dalam 2 Timotius 3:16 disebutkan, bahwa segala tulisan yang diilhamkan (diinspirasikan) Allah memang bermanfaat untuk mengajar, untuk menyatakan kesalahan, untuk memperbaiki kelakuan dan untuk mendidik orang dalam kebenaran. Kata terjemahan "diinspirasikan" dari kata Yunani "theoneustos" secara literal berarti dihembusi, dimasuki angin atau nafas Allah. 2 Petrus1:21 juga dikatakan bahwa "yang terutama harus kamu ketahui ialah bahwa nubuatan

${ }^{14}$ Charles, C. Ryrie, TeologiDasar,Buku 1 (Yogyakarta: YayasanAndi, 1991) 94.

${ }_{15}$ Millard J. Erickson, Teologi Kristen, Volume Satu (Malang: Gandum Mas, 1999) 255.

${ }^{16}$ Rich Cornish, 5 MenitTeologi, ...56-57. 
dalam kitab suci tidak boleh ditafsirkan menurut kehendak sendiri, sebab tidak pernah nubuat dihasilkan oleh kehendak manusia, tetapi oleh dorongan Roh Kudus, orang-orang berbicara atas nama Allah.”

Para nabi juga sering menegaskan bahwa apa yang disampaikan berasal dari Allah. Berkali-kali mereka menyatakan, "Demikianlah firman Tuhan". Nabi Yeremia mengatakan, "inilah perkataan-perkataan yang telah difirmankan Tuhan kepada Israel dan tentang Yehuda (Yeremia 30:4). Yesaya menegaskan, "Sebab beginilah firman Tuhan kepadaku...” (Yesaya 8:11). Tuhan Yesus juga berbicara soal wibawa dan keabadian amanat Alkitab, ketika Dia mengatakan "Kitab Suci tidak dapat dibatalkan" (Yohanes 10:35).

Maka jelaslah karena semua tulisan yang terdapat di dalam Alkitab diinspirasikan oleh Allah, maka dapat diambil dua kesimpulan. Pertama, karena Tuhan yang berfirman; maka Dialah yang menjadi pemilik semua gagasan yang bakal dituliskan menjadi Alkitab. Kedua, semua hamba-Nya (para penulis Alkitab) mengalami dorongan dari Roh Kudus, untuk menuliskan pemberitaan mengenai gagasan ilahi itu. Maka jelaslah karena Alkitab diinspirasikan oleh Allah hal ini dapat menjamin bahwa Alkitab Perjanjian Lama dan Perjanjian Baru dalam naskah asli tidak terdapat satu kesalahan apapun.

Bagaimana dengan naskah-naskah salinan Alkitab? Barangkali tidak ada dukumen yang memiliki salinan yang paling banyak kecuali Alkitab. Naskahnaskah kuno dari Perjanjian Baru saja bisa berjumlah kurang lebih 24.970 melebihi karya apapun di dunia. ${ }^{17}$ Walaupun Alkitab itu diterjemahkan tetapi dikerjakan dengan penuh hati-hati dan ketelitian yang sangat ketat. Penulis setuju seperti apa yang dikatakan oleh Frederic Kenyon yang mengatakan: "Orang Kristen dapat menggenggam seluruh Alkitab di tangannya dan mengatakan tanpa ragu bahwa di tanggannya terletak firman Allah yang benar, yang diturunkan kepadanya dari generasi ke generasi tanpa perubahan yang berarti selama berabad-abad."18

\section{Allah berkuasa dan sanggup menjaga firman-Nya}

Allah itu Mahakuasa tidak dapat dipisahkan dari kedaulatanNya. Kedaulatan Allah sangat ditekankan dalam Alkitab. Allah diperkenalkan sebagai

${ }^{17}$ Josh McDowell, The New Evidence That Demands A Verdict (Nashville: Thomas Nelson Publishers, 1999) 34.

18 Josh McDowell, ApologetikaBuk.ti Yang MenegubkanKebenaranAlkitab, Vulume 1 (Malang: Gandum Mas, 2007) 96. 
Pencipta dan kehendak-Nya sebagai penyebab segala sesuatu yang ada. Berkenaan dengan perbuatan-Nya yang kreatif dibumi dan di Surga, semuanya merupakan kepunyaan-Nya. Allah memiliki otoritas yang mutlak atas semua makhluk di Surga dan semua penghuni bumi. ${ }^{19}$

Allah itu berdaulat berarti Allah mempunyai otoritas tertinggi disurga dan dibumi (1 Tawarikh 29:11). Allah yang Mahakuasa juga dapat diartikan semua otoritas dan kuasa lain harus berada dibawah otoritas kuasa Allah. Berkaitan dengan kedaulatan Allah ini Arthur W. Pink mengatakan demikian:

Menyebut Allah berdaulat sama halnya dengan menyebut-Nya sebagai Yang Mahatinggi, yang berbuat menurut kehendak-Nya terhadap bala tentara langit dan penduduk bumi; dan tidak ada seorangpun yang dapat menolak tangan-Nya dengan berkata kepada-Nya, "Apa yang Kubuat?" (Daniel 4:35). Menyebut Allah berdaulat sama halnya dengan mengumumkan bahwa Dia adalah Yang Mahakuasa, yang empunya segala kuasa disurga dan dibumi, sehingga tak seorang pun dapat mengagalkan keputusan-keputusan nasihat-Nya, menghalangi tujuan-tujuan-Nya, ataupun menentang kehendak-kehendak-Nya (Mazmur115:3). Menyebut Allah berdaulat sama halnya dengan menyebut-Nya sebagai yang “memerintah bangsa-bangsa' (Mazmur22:29), yang menegakkan kerajaan, yang meruntuhkan kerajaan-kerajaan dunia, dan yang menggariskan jalan kehidupan dinasti-dinasti sesuai dengan perkenan-Nya. ${ }^{20}$

Dasar pijakan dari pribadi Allah yang Mahakuasa dan Allah yang berfirman kepada para hamba-Nya ketika proses penulisan Alkitab itu terjadi dapat menjamin bahwa Alkitab itu bersifat ineransi. Allah yang Mahakuasa berarti Allah bisa menjaga dan mengkontrol ketika Alkitab itu dituliskan oleh para hamba-Nya (para nabi, rasul dll). Proses penulisan Alkitab yang demikian menghindarkan berbagai kemungkinan yang keliru. Sebaliknya Allah yang Mahakuasa dapat mengawasi dan mengontrol apapun yang ditulis tidak akan keluar dari kehendak Allah.

${ }^{19}$ Stevri I. Lumintang, Theologia\&Misiologia Reformed (Batu: DepartemenLiteratur PPII, 2006) 103.

20 Arthur W. Pink, The Sovereignty Of God (Terjemahan), (Surabaya: Penerbit Momentum, 2005) 14. 


\section{Ajaran dan kesaksian Kristus terhadap Alkitab}

Tuhan Yesus mengajarkan secara konsisten bahwa Perjanjian Lama adalah firman Allah yang memberi kesaksian tentang diri-Nya. Yesus berkata, "Abraham bapamu bersukacita bahwa ia akan melihat hari-Ku." (Yohanes 8:8:56). Dalam Yohanes 5:46 Dia berkata, "Musa ... menulis tentang Aku." Kalau Yesus mengatakan bahwa Alkitab memberi kesaksian tentang diri-Nya, berarti Yesus sendiri sedang memberi kesaksian tentang Alkitab. ${ }^{21}$

Yesus menegaskan bahwa Perjanjian Lama memiliki otoritas Ilahi (Matius 4:4, 7, 10). Yesus menegaskan kesejarahan Perjanjian Lama dapat dipercaya (Matius 12: 40 bandingkan Matius 16:4; Matius 24:37-38 bandingkan Matius 10:15; 12:42; 19:4-6). Yesus menegaskan bahwa Perjanjian Lama adalah firman Allah. Dia mengatakan, "Kitab Suci tidak dapat dibatalkan." Pada permulaan khotbah di Bukit Yesus mengatakan:

Janganlah kamu menyangka, bahwa Aku datang untuk membatalkan Hukum Taurat atau kitab para nabi. Aku datang bukan untuk meniadakannya, melainkan untuk menggenapinya. Karena itu Aku berkata kepadamu: Sesungguhnya selama belum lenyap langit dan bumi ini, satu iota atau satu titikpun tidak akan ditiadakan dari hukum Taurat, sebelum semuanya terjadi." (Matius 5:17-18).

Kalau Allah dalam Perjanjian Lama telah memanggil para nabi untuk mencatat dan menafsirkan apa yang dibuat-Nya dan diajarkan kepada umat Israel. Demikian pula Yesus telah memanggil para rasul untuk mencatat dan menafsirkan apa yang Dia buat dan katakan lalu mengutus mereka untuk mengajar gereja. Yesus menjanjikan Roh Kudus kepada mereka untuk mengingat tentang pengajaran-Nya dan melengkapi-Nya, dan memimpin mereka ke dalam seluruh kebenaran (Yohanes 14:25-26; 16:12-13). Ini menjelaskan mengapa Yesus saat itu dapat berkata kepada para rasul. "Barang siapa mendengarkan kamu, ia mendengarkan Aku; dan barangsiapa menolak kamu, ia menolak Aku" (Matius 10:40; Lukas 10:16; Yohanes 13:20). Dengan kata lain, Dia menanamkan otoritas-Nya ke dalam mereka, sehingga sikap orang terhadap

21 John R.W. Stott, Alkitab: BukunntukMasaKini Jakarta: Persekutuan PembacaAlkitab, 1987) 16, 20. 
pengajaran mereka mencerminkan sikap mereka kepada-Nya.22Pengakuan Yesus terhadap Perjanjian Lama dan Perjanjian Baru jelas menegaskan bahwa Alkitab dapat dijamin kebenarannya atau bersifat ineran.

\section{Implikasi Doktrin Ineransi bagi Kehidupan Orang-orang Percaya}

Pandangan seseorang terhadap ineransi terkait erat kehidupan orang percaya, dengan demikian pentingnya seseorang memiliki pemahaman yang benar. Berikut ini akan dipaparkan implikasinya bahwa pandangan ineransi sangat memperngaruhi bidang kehidupan orang percaya.

\section{Ineransi berkaitan dengan otoritas Alkitab}

Alkitab itu berkuasa berkaitan dengan sifatnya yang memiliki otoritas bagi fondasi iman bagi orang percaya. Alkitab memiliki otoritas karena semua tulisan yang terdapat di dalam Alkitab merupakan perkataan-perkataan Allah untuk mengatur hidup manusia. Alkitab berotoritas berarti mempunyai kekuasaan atau wewenang untuk mengatur semua aspek hidup manusia. Otoritas atau wibawa Alkitab diterima secara langsung dari Allah, sebab Alkitab adalah hasil pengilhaman (inspirasi) Ilahi. ${ }^{23}$

Posisi Alkitab yang demikian jelas memiliki implikasi yang sangat luas bagi kehidupan manusia. Implikasinya bisa bersifat vertikal dan horizontal. Implikasi yang bersifat vertikal berkaitan dengan hubungan manusia dengan Tuhan Allah. Implikasi yang bersifat horizontal berkaitan dengan hubungan manusia dengan sesamanya. Berhubungan dengan Allah berkaitan semua hal yang dilakukan oleh manusia secara langsung dihadapan Allah, misalnya: persekutuan pribadi dengan Allah, doa, puasa, dll. Berhubungan dengan manusia dan sesama, semua hal yang dilakukan oleh manusia, baik secara sosial, politik, ekonomi, kesenian, olah raga, kesehatan, dll.

Apa yang terjadi jika seseorang menganggap bahwa Alkitab tidak ineransi? Jelas ini berimplikasi luas bagi sikap orang percaya terhadap Alkitab. Penolakan sebagian dari isi Alkitab yang menyatakan adanya sebuah kekeliruan mempunyai

\footnotetext{
${ }^{22}$ Ibid, 23-24.
}

${ }^{23}$ HarunHadiwijono, Iman Kristen (Jakarta: BPK GunungMulia, 1990) 68. 
implikasi yang serius terhadap otoritas Alkitab itu sendiri. Implikasinya menjadikan Alkitab tidak mempunyai wibawa untuk mengatur kehidupan orang-orang percaya.

Akibatnya bisa saja orang percaya menafsirkan secara longgar hal-hal yang berikut: misalnya, pandangan yang longgar terhadap perzinaan. Pandangan yang longgar terhadap homoseksualitas. Pandangan yang longgar terhadap masalah perceraian dan kawin ulang. Masih banyak lagi hal-hal yang diajarkan oleh Alkitab yang jelas bersifat mutlak. ${ }^{24}$

\section{Ineransi berkaitan dengan atribut pribadi Allah}

Salah satu atribut yang dimiliki oleh Allah adalah kemahakuasaan (omnipotence). Istilah omnipotence menunjukkan bahwa Allah adalah mahakuasa. Allah adalah mahakuasa berarti dapat melakukan apa saja yang dikendakinya. Karena Allah mahakuasa, maka segala sesuatu tidak ada mustahil dihadapanNya (Matius 19:26). Ia dapat melakukan segala sesuatu dan tidak ada yang terlalu sukar bagi Allah. Ia melakukan apa yang diinginkan (Mazmur 115:3) dan menetapkan segala sesuatu sesuai dengan kehendak-Nya (Efesus 1:11). ${ }^{25}$

Apa yang terjadi jika Alkitab itu tidak ineransi? Hal ini jelas berimplikasi pada pandangan seseorang dalam memahami atribut Allah yang mahakuasa. Allah dipandang tidak mahakuasa atau dianggap tidak terlalu peduli terhadap makhluk ciptaan-Nya. Akibat lebih jauh seseorang bisa menolak realitas Allah dalam kehidupan manusia. Manusia akan menempatkan dirinya sebagai tolok ukur dalam menentukan setiap kebenaran di dalam kehidupannya.

\section{Ineransi berkaitan dengan pengakuan iman gereja}

Sejak gereja lahir sudah menghadapi dua tantangan dari dua arah yang berbeda. Pertama, tantangan dari dalam gereja. Kedua, tantangan dari luar gereja. Menghadapi dua tantangan tersebut gereja harus memberi jawaban atas permasalahan ada. Untuk memecahkan dan menjawab permasalahan tersebut gereja memerlukan rumusan pengakuan iman. Maka digelarlah konsili yang dihadiri oleh gereja-gereja, misalnya konsili Nicea (325 M), Hippo (393 M), Karthago (419 M).

${ }^{24}$ Charles C. Ryrie, Buku 1 TeologiDasar (Yogyakarta: YayasanAndi, 1991) 102.

${ }^{25}$ Paul Enns, The Moody Handbook Of Theolgy (Malang: Literatur SAAT, 2003) 238239. 
Konsili yang pertama di adakan di Nicea pada tahun $325 \mathrm{M}$ menghasilkan pengakuan iman yang disebut "Pengakuan Iman Nicea". Salah satu rumusannya yang ditetapkan adalah Yesus Kristus adalah pribadi Allah yang sehakikat dengan Allah Bapa. Penyataan tersebut jelas termuat dalam kalimat demikian: .... "Dan kepada satu Tuhan, Yesus Kristus, Anak Allah yang diperanakkan dari Bapa, yang dari hakikat Bapa......Allah sejati dari Allah sejati, yang diperanakkan, bukan dijadikan, sehakikat (bomoousios) dengan Bapa,"....26

Pribadi Kristus yang Ilahi bukan diakui di konsili Nicea saja tetapi juga diteguhkan lagi dalam konsili di Kontantinopel I (381M). Pengakuan iman yang dihasilkan dari sebuah konsili hakikatnya bukan buah pikir dari bapa-bapa gereja tetapi sebuah pernyataan iman yang bersumber dari Alkitab itu sendiri.

Berkaitan dengan masalah ineransi Alkitab, ada sebuah pertanyaan, apa yang terjadi jika Alkitab itu tidak ineransi? Jawabannya jelas akan meruntuhkan semua pengakuan iman yang selama ini diakui dan digunakan oleh gereja-gereja sekarang. Pengakuan iman akan runtuh karena tidak adadasar bagi gereja dan orang Kristen untuk menggunakannya karena sumber hukumnya pada Alkitab sudah diragukan kebenarannya.

\section{Ineransi berkaitan dengan berita keselamatan dalam Alkitab}

Ineransi juga berkaitan dengan berita keselamatan yang diajarkan oleh Alkitab. Seperti diketahui sejak gereja mula-mula lahir di era Perjanjian Baru orang-orang percaya memberitakan Injil keseluruh penjuru bumi. Pemberitaan Injil dilakukan sebagai respons dalam mentaati perintah amanat agung dari Tuhan Yesus ketika berkata kepada murid-murid-Nya sebelum naik ke surga (Matius 28:19-20; Kisah Para Rasul1:8).

Karena berita keselamatan diberitakan ke seluruh penjuru bumi maka lahirlah gereja-gereja diseluruh dunia. Apa yang terjadi jika ternyata di dalam Alkitab kebenarannya masih diragukan? Jelas ini akan melemahkan semangat orang percaya untuk melakukan misi Injil ke seluruh dunia, bahkan akan meruntuhkan dasar orang percaya karena tidak ada dasar yang kuat bagi pijakan untuk melakukan penginjilan.

Pemberitaan Injil bukan hanya terhenti, tetapi orang percaya mulai meragukan apa betul Yesus sebagai satu-satu juru selamat bagi orang bedosa.

26 Tony Lane, RuntutPijarSejarabPemikiranKristiani (Jakarta: BPK GunungMulia, 1993) 24. 
Orang-orang percaya mulai mencari keselamatan di luar Yesus karena berita keselamatan yang diajarkan oleh Alkitab tidak bisa diandalkan lagi. Dampak lainnya gereja sebagai sebuah persekutuan dan institusi tidak perlu membentuk komisi misi (penginjilan) karena sudah dianggap tidak relevan lagi.

\section{Ineransi berkaitan dengan pedoman praktis kehidupan orang Kristen}

Topik ineransi merupakan bagian dari teologi Kristen. Salah satu tugas dari teologi diantaranya adalah menyusun pengertian-pengertian dasar iman Kristen yang diharapkan dapat mendorong pembentukan spiritualitas yang lebih kokoh. Teologi bukan hanya bicara masalah keabadian, tetapi harus bisa memberi panduan baik secara langsung maupun tidak secara langsung hal-hal yang dihadapi oleh orang Kristen dalam kehidupan sehari-hari. Pandungan ini memberikan dasar terhadap prinsip-prinsip kehidupan Kristen dalam mengambil keputusan seperti etika, ekonomi, ilmu sains, keuangan, dll.

Apa yang terjadi jika orang percaya mulai meragukan kebenaran Alkitab? Apa yang terjadi jika orang percaya mulai menganggap bahwa Alkitab itu memiliki kelemahan? Dampaknya jelas akan menghancurkan otoritas Alkitab bagi kehidupan orang-orang percaya. Alkitab tidak bisa dijadikan satu-satunya pedoman praktis bagi kehidupan sehari-hari karena dianggap memiliki banyak kekurangan. Orang percaya tidak bisa menjadikan Alkitab sebagai pedoman hidup dalam memutuskan hal-hal yang berkaitan dengan masalah ekonomi, politik, perdagangan dll. Alkitab disamakan dengan buku-buku umum lainnya yang juga memiliki ketidaksempurnaan.

\section{KESIMPULAN}

Ajaran ineransi sangat penting untuk dipahami oleh semua orang percaya. Ineransi Alkitab penting untuk dipelajari karena berkaitan dengan fondasi iman Kristen. Alkitab menjadi fondasi iman Kristen karena menjadi referensi utama bagi orang percaya dalam mengambil keputusan ketika menghadapi berbagai kesulitan kehidupan.

Apa yang dipercayai itulah yang menjadi pedoman bagi setiap orang percaya. Apa yang terjadi jika yang dipercayai ternyata memiliki satu kelemahan, hal ini pasti berdampak dengan semua doktrin iman Kristen lainnya. Maka pengertian ineransi yang benar sangat berpengaruh terhadap sikap orang dalam memperlakukan Alkitab itu sendiri. 
Ada beberaapa dasar yang menjadi pijakan bagi orang percaya bahwa Alkitab adalah ineransi. Pijakan ini semua berasal dari kebenaran yang tertulis dalam Alkitab. Pertama, Allah itu tidak dapat berbuat salah. Kedua, Alkitab ditulis dengan proses insprirasi dari Allah. Ketiga, Allah berkuasa dan sanggup menjaga firman-Nya. Keempat, Ajaran dan kesaksian Kristus terhadap Alkitab.

Pemahaman ineransi Alkitab itu penting karena pemahaman yang benar bisa berimplikasi dalam berbagai bidang kehidupan orang percaya. Implikasinya yaitu: ineransi berkaitan dengan otoritas Alkitab. Ineransi berkaitan dengan atribut pribadi Allah. Ineransi berkaitan dengan pengakuan iman gereja. Ineransi berkaitan dengan berita keselamatan yang diajarkan oleh Alkitab. Ineransi berkaitan dengan pedoman praktis kehidupan orang Kristen.

\section{Rekomendasi}

Setiap hamba Tuhan perlu mengajarkan kepada anggota jemaat tentang pengertian ineransi yang benar. Pengertian yang benar penting supaya jemaat tidak terombang ambing dengan pengajaran yang menyesatkan. Pengertian yang benar bisa menolong jemaat ketika harus menjawab berbagai tantangan dan kesulitan kehidupan. Alkitab dijadikan satu-satunya tolok ukur dalam mencari kebenaran.

SUNARTO, S.Th, M.A menyelesaikan program Sarjana Muda Teologi di Sekolah Tinggi Teologi Injili Efrata (STTI Efrata) Sidoarjo; Sarjana Teologi dan Master of Art dari Sekolah Tinggi Teologi Injili Abdi Allah (STT IAA) di Pacet Mojokerto. Sekarang sedang dalam tahap akhir penyelesaian studi Magister Teologi di Sekolah Tinggi Baptis Indonesia (STBI) di Semarang.Saat ini melayani sebagai dosen dan ketua STT SAPPI Ciranjang Cianjur. 